\title{
Evaluating the Relationship of Knowledge, Attitudes, and Practices of Home Delivery Handlers Regarding Avoid COVID-19 in Quick Service Restaurants Suzan Elsayed Abdelrassoul ${ }^{1} \quad$ Hany Atef Kozmal $^{2}$ \\ ${ }^{1}$ High Institute of Tourism and Hotel Management and Monuments Restoration-Abu kir, ${ }^{2}$ High Institute for Tourism and Hotel Management (EGOTH)- Luxor City
}

\begin{abstract}
Home delivery is one of the most critical steps in the food cycle regarding avoid COVID-19 in quickservice restaurants. The home delivery must meet or exceed food safety and hygienic practices because guest safety is the overall goal of foodservice. Therefore, home delivery is a complex process, but it can be successful when it focuses on guest needs and expectations. This study aims to measure the awareness, knowledge, and practices of food delivery handlers regarding home delivery procedures in order to apply the HACCP steps to protect food delivered from COVID-19 in quickservice restaurants. To achieve that, 600 self-administered questionnaires were distributed to home delivery handlers to ensure that proper hygienic home delivery practices during procedures are applied. The data were analyzed by SPSS program version 20. The result indicated that home delivery handlers know the right knowledge regarding avoiding COVID-19but they did not know how to apply it .As the total score of Attitudes and knowledge of food handlers mean is 4.52and, it is an excellent score, while the score of home delivery practices means is 3.86 and mean 3.32 in-home delivery area and equipment.
\end{abstract}

Keywords: Home Delivery, COVID-19, Quick Service Restaurants, Food Hygienic Practices, Food Handlers.

\section{Research objectives}

1. The research objectives are to:

2. Assessment of food safety and COVID-19 knowledge and attitudes of home delivery food handlers.

3. Assessment of food safety practices of home delivery food handlers' actual application of these procedures.

4. Assessment the role of restaurant management and its policy in entitles home delivery handlers to the importance of the avoid COVID-19.

\section{Introduction}

Corona virus COVID-19

It is highly improbable that people can contract COVID-19 from the restaurants' food or food packaging. COVID-19 is a respiratory illness, and the transmission route is from person-toperson contact and through direct contact with an infected person coughs or sneezes.

There is no evidence to date of viruses that cause respiratory illnesses being spread via food or food packaging. COVID-19 viruses need an animal or human host to multiply and cannot multiply in food(World Health Organization (WHO), 2020 ${ }^{\mathrm{a}}$ ).

Recent research evaluated the existence of the COVID-19 virus on different surfaces and described that the virus could remain viable for up to 72 hours on stainless steel and plastic, up to four hours on copper, and up to 24 hours on cardboard. This research was directed under laboratory environments (controlled relative humidity and temperature) and should be interpreted with caution in the real-life environment(Fuchs, 2020; World Health Organization (WHO), $\left.2020^{\mathrm{a}}\right)$.

It is imperative for the quick service restaurants industry to reinforce personal hygiene measures and provide training on food hygiene principles to avoid or decrease the risk of food surfaces and home delivery packaging materials becoming contaminated with the virus from food workers. 
Personal protective equipment (PPE), such as gloves and masks, can reducing the spread of viruses and disease within the quick service restaurants industry, but only if used accurately(World Health Organization (WHO), 2020 b).

The coronavirus-disease (COVID-19) is a highly infectious respiratory disease. Common symptoms include fever, shortness of breath, a dry cough, and extreme tiredness. The first patient suffering from the disease was identified on December 2019 in Wuhan (Fuchs, 2020 ; Zhu et al., 2020). A new respiratory coronavirus is rapidly spreading throughout the world (Fuchs, 2020a ; Tabish, 2020).

Unlike the most common way of going to a restaurant, for getting take away or ordering delivery. People order food delivery service since they don't like to cook; primarily clients could have food delivered directly to their home or office in less than 60 minutes (Rathore \& Chaudhary, 2018).

\section{The benefit of food delivery applications}

Easy to use, flexible payments, real-time tracking, loyalty points, and adequate customer support(Gupta, 2019).

1. Easy to use: The food ordering with mobile apps is easier to use and offer high convenience with time, effort saving and more for the customers satisfaction.

2. Flexible payments: mobile apps offer flexible payment options for the customers to be able to pay using various modes of payments, best suitable for them.

3. Real-time tracking: the consumers can track the delivery boy bringing their food, along with helping the delivery handlers to track down the exact address of the customers.

4. Loyalty points: Online food ordering often offers loyalty points for encouraging customers to use the mobile app more.

5. Adequate customer support With 24/7 customer support facilities such as the mobile apps, answering to customers queries, and assisting them in any need or comments (Curtis, 2016; Fuchs, 2020c).

Online ordering has been growing as a requirement have a factor for the restaurants. Online ordering has taken the restaurants by a storm. Technology develops the food delivery service, puts a buried impact on the business industry, technology has changed the entire frame of quickservice restaurants industry. A technically developed online food ordering system has changed the quick service restaurant culture gives a new unique comfort zone to customers across the globe (Curtis, 2016).

With an online food ordering system, a restaurant can be set up, and the customers can easily order. Also, with a quick service restaurant menu online, orders can be easily tracked, it upholds customers' database. The quick-service restaurants can even modify the online restaurant menu and upload images simply. Customers can easily access a restaurant menu on the internet and place orders at their convenience (Singh et al., 2017).

\section{Impact on restaurant}

Customer Experience

1. If customers like the service, they will come back and also recommend the restaurant to their world.

2. People do not want to spend 5-6 minutes as they place their order over the phone by looking at the ordering menu and pause whatever work they were doing.

3. One thing online ordering will undoubtedly do is "up your game" when it comes to providing a better service by making the ordering process convenient.

4. When customers pick up their smartphones to use the restaurant online ordering system, they will do it. 
5. Customers can order their favorite food by clicking on the screen a few times and they do it from their homes(Hill, 2015; Trejos, 2015).

Positive and Negative Effects of food delivery app on restaurant

Optimistic: When done right, delivery can help restaurant operators cultivate customer loyalty and enhance profitability: It is just one click away and it's fast, easy and comfortable.

Negative: The outlook for fine dining restaurants is vital because they place a premium on taste, while new ordering and delivery platforms mainly focus on convenience and price, the delivery business is growing so fast, it's giving restaurants cause to rethink their expansion strategies too(Gupta, 2019).

Online food delivery mobile applications have become popular. There are wide varieties of restaurants now delivering online services (Hill, 2015; Priyadharshini, 2017). Many restaurants are witnessing an increase in business, as ordering food online becomes more and more popular. An online food menu is created in each mobile application(Jacob et al., 2019).

Mobile applications like Zomato, Swiggy, and Uber Eats provide the customers countless varieties of dishes from different nearby restaurants and customers can easily place the order; most users favor online apps to get food delivered right at their door instantly. This, in a way, has boosted the restaurant business widely(Priyadharshini, 2017).

These mobile applications provide a tracking system where the customers become more acquainted with each progression of delivery. They place the order in the respective restaurant and customers can track the order. The payment options include either online or by cash-ondelivery (COD) systems (Jacob et al., 2019).

Good staff hygienic practices include:

- Proper hand hygiene - washing with soap and water for more than 20 seconds (follow WHO advice);

- Frequent use of alcohol and hand sanitizers.

- Good respiratory hygiene (cover mouth when coughing or sneezing; dispose of tissues and wash your hands).

- Frequent cleaning of work surfaces and touchpoints.

- Avoiding close contact with anyone showing symptoms of respiratory illness such as coughing and sneezing(World Health Organization (WHO), 2020a).

Cleaning is the removal of foreign material. This includes dust, soil, and organic material that may include blood, secretions and microorganisms. Cleaning reducing the microorganism load on a surface(World Health Organization (WHO), 2020b).

Disinfection is a process used on inanimate objects and surfaces to kill microorganisms. Disinfection will kill most disease-causing microorganisms but may not kill all bacterial spores. Only sterilization will kill all forms of microbial life(World Health Organization (WHO), 2020c).

- Clean first and then disinfect: organic material de-activates disinfectant solutions.

- Proper contact time: different products require varying 'wet' times to kill microorganisms.

- Proper mixture: the concentration is strong enough to clean but not so healthy to be harmful to staff and patients.

- Regular changes in cleaning equipment and tools.

- Use of the accurate Personal Protective Equipment (PPE) to protect healthcare workers (Fuchs, 2020c). 
Risk communication uses many communications techniques such as media, mass communications, social media communications, and community engagement. It requires the understanding of concerns and beliefs, knowledge and practices (World Health Organization (WHO), 2020d).

The contamination levels of the disinfectant solution and equipment used for cleaning can be minimized by:

- Starting the cleaning task by wearing disposable gloves and performing hand hygiene

- Ensuring proper disinfectant mixing

- Frequently changing the disinfectant solution

- Frequently changing the cleaning mop heads

- Not dipping a soiled cloth into the disinfectant solution(World Health Organization (WHO), 2020c).

The speedy propagation of the coronavirus, along with its ability to infect most of the countries in the world remarkably fast, has inspired the novel proposed in this work, named Coronavirus Optimization Algorithm (CVOA) (Martínez-Álvarez et al., 2020).

When showing to fast-changing information, be it a new technology or an emerging crisis before acting on disapprovingly about the source of information could think it (Reeves et al., 2020).

Humans avoid face-to-face social relations and use instead of telephone and social media, messenger and video communication software such as WhatsApp, Telegram, Zoom, and Skype. Social distancing is communication and sociality at a distance, not a distancing from the other humans(Fuchs, 2020b).

Communication technologies play an essential role in the restaurants under the exceptional conditions that the coronavirus crisis poses for society and individuals. Primary means of communication are by and large avoided. There is the wide use of mediated communication with the help of secondary, tertiary means of communication (Li et al., 2020). Generally, Quick Service Restaurants should arm themselves with an internal COVID-19 response team, which includes a member from every department critical to the restaurant business. This team should be responsible for keeping a pulse on continually brainstorming adjustments to strategy and presenting to managers to take action (Mangan, 2020).

Research framework and hypothesis

There are statistically significant relationships between home delivery area, home delivery handlers knowledge, attitudes, and practices of food safety against COVID-19 of selected restaurants, as shown in Figure 2.

H 1: There is a statistically significant relationship between the home delivery area and home delivery practices.

H 2: There is a statistically significant relationship between the home delivery area and attitudes and knowledge of food handlers.

H 3: There is a statistically significant relationship between the home delivery practices and attitudes and knowledge of food handlers figure 1. 
Figure 1: Research Hypotheses.

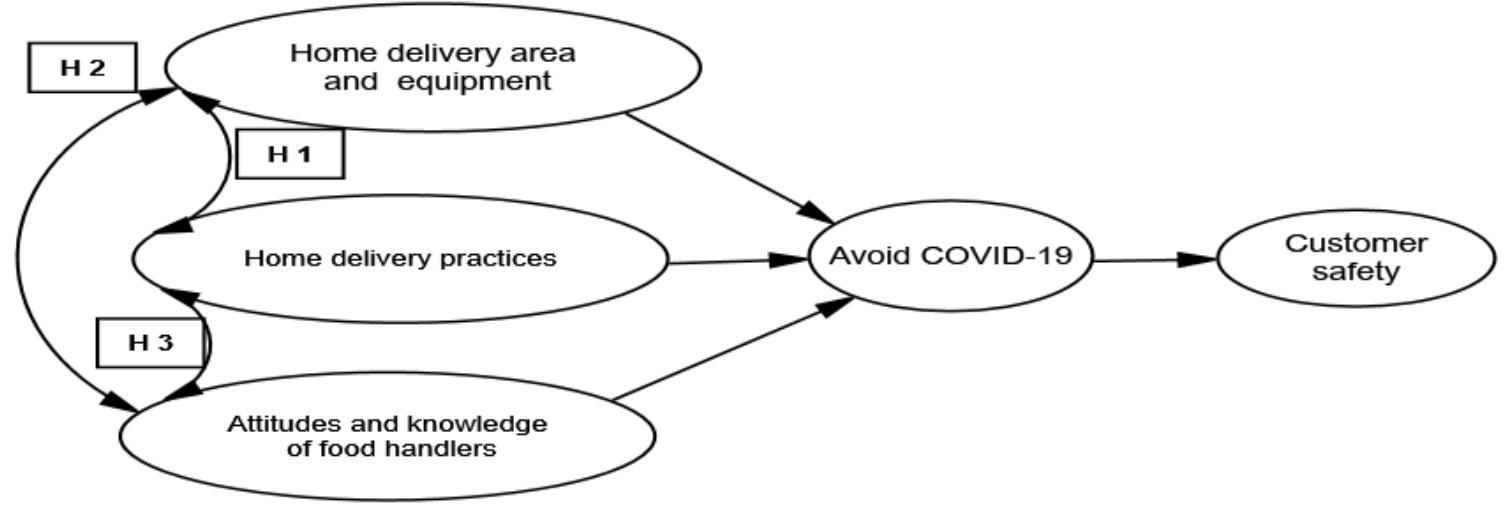

\section{Materials and methodology}

Questionnaires provide an efficient way of collecting a large amount of data from a sizable population of home delivery workers in a highly economical way. The questionnaire consists of three parts or dimensions: home delivery area and equipment, home delivery practices and attitudes and knowledge of food delivery handlers.

A pilot study was conducted in this study in February 2020. The pilot study aimed to find out where and how could evaluate the relationship of knowledge, attitudes and practices of home delivery handlers regarding avoid COVID-19 in Quick Service Restaurants. Moreover, to ensure that the survey was well designed and easily understood by potential respondents, to examine the reliability and validity of the research tools as well as to develop and refine measure of the questions. Questionnaire was reviewed by some academic scholars to establish their appropriateness, clarity and to ease the understanding. Some amendments were suggested and then were implemented. Questionnaire was then pre-tested in order to investigate the respondent's understanding of scale items and to identify also any issues that was complex or confusing in order to develop appropriate scale items to ensure the validity and reliability of the research. For this purpose, a self-administered questionnaire was distributed to a sample of home delivery handlers and supervisors. A number of 40 forms were distributed to respondents who were asked to complete them. Only, 32 completed forms were valid which represents $80 \%$ rate of response.

The field study was accomplished through a survey by phone calls, social media networks, and emails. The target population for this study was Home delivery handlers at Egyptian restaurant from March to May 2020. A cross-sectional study of home delivery handlers in the Quick service restaurants that serve Home delivery was conducted questionnaire forms which distributed on the internet on face book, e-mail and google drive https://docs.google.com/forms/d/1ShBPwCZvH5Pb2UP011wDu4zH8hgrI4ZZTRfsqSCRsdg/edi $\underline{t}$ to evaluate the relationship of knowledge, attitudes and practices of home delivery handlers regarding avoid covid-19 in quick service restaurants. A number of 600 questionnaire forms were received only 434 completed forms were valid (72.33\%valid rate). The collected data were analysed using SPSS version 20. A survey was carried out on quick-service restaurants home delivery handlers in order to evaluate the relationship of knowledge, attitudes and practices of home delivery handlers regarding avoid COVID-19.

\section{Study instrument reliability}

For all scales, Cronbach's Alpha, the correlation coefficient was calculated to regulate the internal consistency of the scale; the Reliability coefficient is 0.99 ; it is over0.70; it is considered "strongly acceptable" in most social science situations. The Cronbach's Alpha reliability was 
computed and the tests showed that the reliability coefficients for all the instruments were above 0.99, which indicates that the instrument was reliable for being used. Cronbach alpha for all survey instruments was shown in the following table: 1.

Table 1: Reliability Statistics

\begin{tabular}{|c|c|c|}
\hline Cronbach's Alpha & No. of Items & No of questionnaires \\
\hline .994 & 69 & 434 \\
\hline
\end{tabular}

\section{Results:}

This part of the study included the results of the questionnaire forms, which were distributed to evaluate the relationship of knowledge, attitudes and practices of home delivery handlers regarding avoid covid19 in quick-service restaurants. Statistical package of social sciences (SPSS) version 20.0 for windows was used to analyze and compute the collected data, except for the open question. Frequencies counts and percentage distributions were used to evaluate the relationship of knowledge, attitudes and practices of home delivery handlers regarding avoiding COVID-19 in Quick Service Restaurants.

Table 2: Respondent's Demographic Data Analysis

\begin{tabular}{|l|l|c|c|}
\hline \multicolumn{1}{|c|}{ Personal data } & Frequency & Percent (\%) \\
\hline \multirow{4}{*}{ Age } & Less than 20 years & 192 & 44.2 \\
\cline { 2 - 4 } & From 20 years to less than 35 years & 226 & 52.1 \\
\cline { 2 - 4 } & From 35 years to less than 45 years & 16 & 3.7 \\
\cline { 2 - 4 } & Total & 434 & 100.0 \\
\hline \multirow{5}{*}{ Qualification } & Master or PhD & 12 & 2.8 \\
\cline { 2 - 4 } & High qualified & 318 & 73.3 \\
\cline { 2 - 4 } & Qualification above average & 52 & 12.0 \\
\cline { 2 - 4 } & Middle Certification & 36 & 8.3 \\
\cline { 2 - 4 } & Without a degree & 16 & 3.7 \\
\cline { 2 - 4 } & Total & 434 & 100.0 \\
\hline \multirow{5}{*}{ Function } & Manager & 12 & 2.8 \\
\cline { 2 - 4 } & Supervisor & 52 & 85.3 \\
\cline { 2 - 4 } & Team member & 370 & 100.0 \\
\cline { 2 - 4 } & Total & 434 & $(\mathrm{n}$ \\
\hline
\end{tabular}

The distribution of the studied delivery handlers according to demographic data $(\mathrm{n}=434)$ indicated that the percentage of studied delivery handlers was $96.30 \%$ at the age of fewer than 35 years. High educated delivery handlers have a great percentage of $73.3 \%$ of all food handlers; the lowest percentage was $2.8 \%$ Master or PhD. The most significant percentage was $85.3 \%$ of the job team member and the lowest percentage was the manager $2.8 \%$ table (2).

The distribution of the Respondent's ordering preferences indicated that customers prefer eating the highest percentage of studied requesting home delivery was $64.1 \%$; while the lowest was take his request from the restaurant outside (take away) by percentage $12.9 \%$. Regarding how customers prefer to order home delivery by calling directly to your favorite restaurant has a great percentage of $59.4 \%$ table (3).

Table 3: Respondent's ordering preferences

\begin{tabular}{|l|l|c|c|}
\hline \multicolumn{2}{|c|}{ Ordering preference } & Frequency & Percent (\%) \\
\hline \multirow{2}{*}{\begin{tabular}{l} 
How $\begin{array}{l}\text { customers } \\
\text { prefer eating }\end{array}$ \\
\cline { 2 - 4 }
\end{tabular}} & Eat it at the restaurant & 100 & 23.0 \\
\cline { 2 - 4 } & Take his request from the restaurant outside (take away) & 56 & 12.9 \\
\cline { 2 - 4 } & Requesting home delivery & 278 & 64.1 \\
\cline { 2 - 4 } $\begin{array}{l}\text { How } \\
\text { customers }\end{array}$ & Total & 434 & 100.0 \\
\cline { 2 - 4 } & Food delivery applications & 20 & 4.6 \\
\hline
\end{tabular}




\begin{tabular}{|l|l|c|c|}
\hline \multicolumn{1}{|c|}{ Ordering preference } & Frequency & Percent (\%) \\
\hline \multirow{2}{*}{$\begin{array}{l}\text { prefer to } \\
\text { order home } \\
\text { delivery }\end{array}$} & By calling directly to your favorite restaurant & 258 & 59.4 \\
\cline { 2 - 4 } & Others & 16 & 3.7 \\
\cline { 2 - 4 } & Total & 434 & 100.0 \\
\hline
\end{tabular}

According to the first dimension: Home Delivery Area and Equipment table (3) showed that $(92.63 \%)$ of studied samples of home delivery handlers indicated that in accordance to the $1^{\text {st }}$ acceptance average level was the restaurant have a delivery area, with a mean (4.63) and Std (0.64). In the $2^{\text {nd }}$ position with $(83.41 \%)$ indicate that the uniform is uniformly clean and antiseptic, with a mean (4.17) and Std (0.93). About the $3^{\text {rd }}$ priority $(80.41 \%)$ of them indicated that the floors are always clean and dry, and dirt and debris are removed and chlorinated efficiently, with a mean (4.02) and Std (0.87). Followed in the $4^{\text {th }}$ importance $(73.27 \%)$ of them indicated that the delivery motorcycle and box is clean and continuously cleansed, with a mean (3.66) and $\operatorname{Std}(0.81)$. Concerning the $5^{\text {th }}$ agree level with $(73.04 \%)$ of them indicated that the delivery bag is clean and continually sanitized, with a mean (1.87) and Std (0.88).

On the other hand, in the last position, there is a health supervisor or doctor to follow by percentage (37.42), with a mean (1.87) and Std (0.88). Is there no smoking in the delivery service area is the $16^{\text {th }}$ efficiency average by the percentage of $(50.78 \%)$, with a mean $(2.53)$ and Std (0.65). Regarding the $15^{\text {nd }}$ agree position where is a thermometer available to measure temperature by a percentage of $(56.91 \%)$ with a mean $(2.84)$ and Std (1.40).In the $14^{\text {th }}$ position is the restaurant having an internal COVID-19 response team, by a percentage of $(58.57 \%)$ as agree average, with a mean (2.84) and Std (1.40). Concerning the $13^{\text {th }}$ level, the agrees average was $(59.26 \%)$ regarding agree with that is the delivery handlers assured personal distance, with a mean (3.14) and Std (0.70).

Regarding the second dimension: home delivery practices table (4) showed that in accordance with the $1^{\text {st }}$ acceptance average level was do the drivers encourage the guest to buy meals through online delivery service. With (96.31\%) average, mean (4.81) and Std (0.38). In the $2^{\text {nd }}$ position were that isolation and immediate analysis of those who show symptoms of corona infection, by a percentage of (94.1\%) as agree average, with a mean (4.70) and Std (0.64). The application of food safety programs allows for a positive impact on the knowledge, attitudes, and practices of QS staff coming in the $3^{\text {rd }}$ priority to the respondents with agree average level (90.78\%), mean (4.53) and Std (0.65). Followed in the $4^{\text {th }}$ importance with $(90.41 \%)$ as an acceptance average, do delivery handlers feel anxious while trading cash, with a mean (4.52) and Std (0.67). Concerning the $5^{\text {th }}$ agree level was smoking in designated areas only and not during food handling by average $(87.65 \%)$, with Std (0.73) and mean (4.38).

On the other side, the last position was that develop a Prevention Plan through having medical exams measured continuously, by percentage (56.31), with a mean (2.81) and Std (0.49). The temperature of the workers is measured continuously is in the $30^{\text {th }}$ efficiency average by the percentage of $(56.96 \%)$, with a mean $(2.84)$ and Std (0.75). Regarding $29^{\text {th }}$ agree position where that medical survey of all employees is done regularly by a percentage of $(60.65 \%)$ with a mean (3.03) and Std (0.63).In the $28^{\text {th }}$ positionis the money being cleaned and disinfected continuously in the case of not dealing with electronic payment by a percentage of $(65.25 \%)$ as agree average, with a mean (3.26) and Std (1.55). Concerning the $27^{\text {th }}$ level, agrees average was $(65.99 \%)$ regarding agree with that is the shoe thoroughly disinfected with chlorine to avoid the transmission of the virus, with mean (3.30) and Std (0.85).

According to the third dimension: Attitudes and knowledge of food handlers the results in a table (5) showed that in accordance with the $1^{\text {st }}$ acceptance average level was that have delivery handlers been educated about coronavirus and how to avoid it, with (98.16 \%) average, mean 
(4.90) and Std (0.29). In the 2nd position was that did delivery handlers know that spray should be avoided, by a percentage of $(97.24 \%)$ as agree average, with a mean (4.86) and Std (0.34).coming in the 3rd priority to the respondents both of that when sneezing, it is preferred in a tissue used once. In the absence of it, the elbow is used and the hand is not used, and when sneezing, delivery handlers should not sneeze on food surfaces, with agree average level (96.50\%), mean was (4.82) and Std (0.38).Followed in the 4th importance with (96.31\%) as an acceptance average for both of did delivery handlers know that hands should be washed, dried, and cleaned well after washing them while handling cash, and Did delivery handlers know that hands should be cleaned well with alcohol after circulation of cash in the absence of soap and water, with a mean (4.81) and Std (0.38).Concerning the 5th agree level were both of did the delivery handlers know that hands should be cleaned well with alcohol after circulation of cash in the absence of soap and water, and did delivery handlers know that hands should be thoroughly cleansed with alcohol after the bell rings or touch any door handles in case, water and soap are not available by average (94.47 \%), with Std (0.44) and mean (4.72).

On the other side, the last position was that do delivery handlers know the importance and how to use chlorine, alcohol and antiseptics by percentage (77.42), with a mean (3.87) and Std (0.77). Do delivery handlers food safety training programs or courses such as communication and the Prevention Plan was in the $12^{\text {th }}$ efficiency average by percentage of $(82.03 \%)$, with a mean (4.10) and Std (0.74). Regarding $11^{\text {th }}$ agree position where that did delivery handlers know that the shoes should be thoroughly disinfected with chlorine to avoid the transmission of the virus by a percentage of $(83.59 \%)$ with a mean (4.18) and Std (0.89). In the $10^{\text {th }}$ position is did delivery handlers know that wearing gloves should be worn while handling food by a percentage of $(82.67 \%)$ as agree average, with a mean (4.13) and Std (0.87). Concerning the 9th level agrees average was $(85.25 \%)$ regarding agreeing with that both of was food safety and hygiene awareness assured and did delivery handlers know that the face should be covered with a mask while handling food. With mean (4.26) and Std (0.86). 
Table (3): Distribution of the studied handlers according to home delivery area and equipment $(\mathrm{n}=434)$

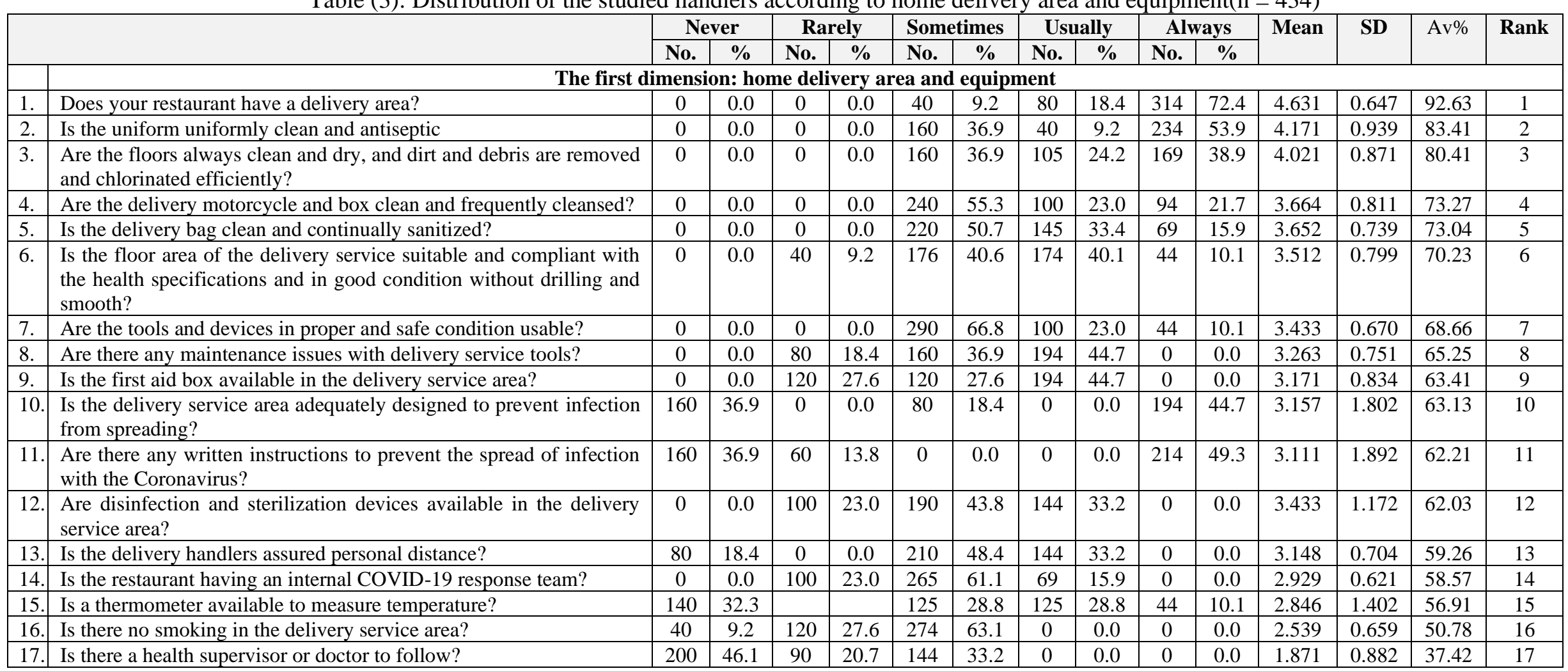

Table (4): Distribution of the studied handlers according to home delivery practices ( $n=434)$

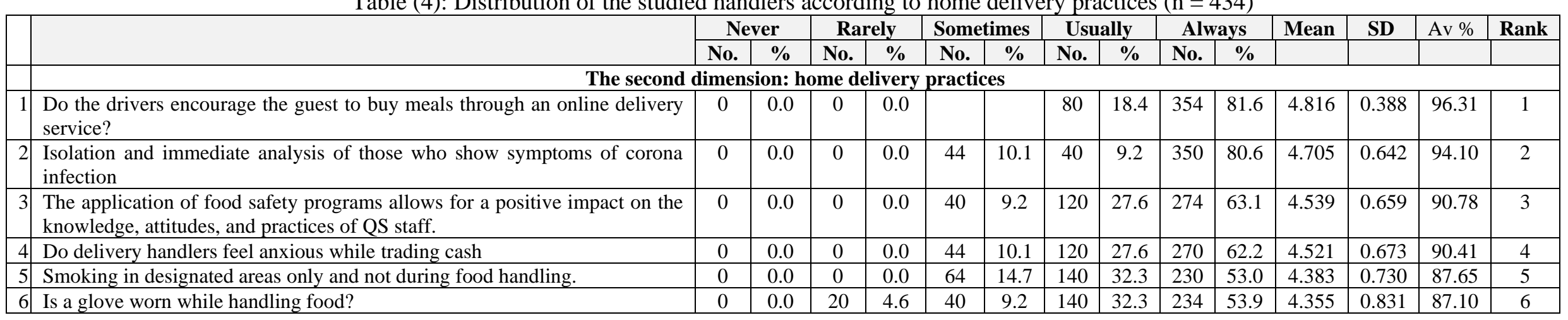




\begin{tabular}{|c|c|c|c|c|c|c|c|c|c|c|c|c|c|c|c|}
\hline & & \multicolumn{2}{|c|}{ Never } & \multicolumn{2}{|c|}{ Rarely } & \multicolumn{2}{|c|}{ Sometimes } & \multicolumn{2}{|c|}{ Usually } & \multicolumn{2}{|c|}{ Always } & \multirow[t]{2}{*}{ Mean } & \multirow[t]{2}{*}{ SD } & \multirow[t]{2}{*}{$\mathrm{Av} \%$} & \multirow[t]{2}{*}{ Rank } \\
\hline & & No. & $\%$ & No. & $\%$ & No. & $\%$ & No. & $\%$ & No. & $\%$ & & & & \\
\hline 7 & Is the uniform cleaned and disinfected continuously & 0 & 0.0 & 0 & 0.0 & 112 & 25.8 & 116 & 26.7 & 206 & 47.5 & 4.217 & 0.829 & 84.33 & 7 \\
\hline 8 & Are fresh and safe food raw materials chosen when handling food? & 0 & 0.0 & 0 & 0.0 & 92 & 21.2 & 163 & 37.6 & 179 & 41.2 & 3.613 & 1.220 & 84.01 & 8 \\
\hline 9 & Is a unique and clean uniform worn during food handling? & 0 & 0.0 & 0 & 0.0 & 116 & 26.7 & 120 & 27.6 & 198 & 45.6 & 4.189 & 0.830 & 83.78 & 9* \\
\hline 1 & $\begin{array}{l}\text { Do delivery handlers make sure to leave the safe distance during trading and } \\
\text { dealing more than a meter according to the WHO Bulletin } 2020\end{array}$ & 0 & 0.0 & 0 & 0.0 & 116 & 26.7 & 120 & 27.6 & 198 & 45.6 & 4.189 & 0.830 & 83.78 & 9* \\
\hline 1 & $\begin{array}{l}\text { Are delivery handlers encouraging customers to serve the delivery service in } \\
\text { particular these days in the presence of corona }\end{array}$ & 0 & 0.0 & 0 & 0.0 & 160 & 36.9 & 64 & 14.7 & 210 & 48.4 & 4.115 & 0.917 & 82.30 & 10 \\
\hline 1 & $\begin{array}{l}\text { Do you observe following the health rules to prevent the spread of } \\
\text { infection? }\end{array}$ & 0 & 0.0 & 0 & 0.0 & 100 & 23.0 & 180 & 41.5 & 154 & 35.5 & 4.124 & 0.756 & 82.49 & 11 \\
\hline 1 & Is the delivery bag cleaned and disinfected continuously & 0 & 0.0 & 0 & 0.0 & 120 & 27.6 & 170 & 39.2 & 144 & 33.2 & 4.055 & 0.779 & 81.11 & 12 \\
\hline 1 & Is clean and safe water used? & 0 & 0.0 & 0 & 0.0 & 80 & 18.4 & 260 & 59.9 & 94 & 21.7 & 4.032 & 0.633 & 80.65 & 13 \\
\hline 1 & $\begin{array}{l}\text { It is concerned with applying the appropriate system for the effectiveness of } \\
\text { food safety programs positively to avoid corona. }\end{array}$ & 0 & 0.0 & 0 & 0.0 & 200 & 46.1 & 40 & 9.2 & 194 & 44.7 & 3.986 & 0.954 & 79.72 & 14 \\
\hline 1 & Eating only in designated areas, not while handling food. & 0 & 0.0 & 0 & 0.0 & 160 & 36.9 & 130 & 30.0 & 144 & 33.2 & 3.963 & 0.837 & 79.26 & 15 \\
\hline 1 & Are tools and devices disinfected and sterilized in the delivery service area? & 0 & 0.0 & 0 & 0.0 & 200 & 46.1 & 65 & 15.0 & 169 & 38.9 & 3.929 & 0.920 & 78.57 & 16 \\
\hline 1 & Are food safety programs supported to avoid corona & 0 & 0.0 & 0 & 0.0 & 184 & 42.4 & 131 & 30.2 & 119 & 27.4 & 3.850 & 0.823 & 77.00 & 17 \\
\hline 1 & $\begin{array}{l}\text { Are the hands thoroughly washed with water and soap for not less than } 20 \\
\text { seconds and continuously cleansed? }\end{array}$ & 0 & 0.0 & 0 & 0.0 & 200 & 46.1 & 110 & 25.3 & 124 & 28.6 & 3.825 & 0.847 & 76.50 & 18 \\
\hline 2 & Is the motorcycle cleaned and disinfected continuously? & 0 & 0.0 & 0 & 0.0 & 184 & 42.4 & 166 & 38.2 & 84 & 19.4 & 3.770 & 0.752 & 75.39 & 19 \\
\hline 2 & Is the junction box cleaned and disinfected continuously & 0 & 0.0 & 0 & 0.0 & 200 & 46.1 & 140 & 32.3 & 94 & 21.7 & 3.756 & 0.787 & 75.12 & 20 \\
\hline 2 & Is electronic payment being used to reduce money circulation? & 0 & 0.0 & 0 & 0.0 & 212 & 48.8 & 143 & 32.9 & 79 & 18.2 & 3.694 & 0.760 & 73.87 & 21 \\
\hline 2 & Will the glove be changed after every cash transaction? & 0 & 0.0 & 92 & 21.2 & 104 & 24.0 & 94 & 21.7 & 144 & 33.2 & 3.668 & 1.146 & 73.36 & 22 \\
\hline 2. & Is disinfection and sterilization in the delivery service area frequently? & 0 & 0.0 & 60 & 13.8 & 180 & 41.5 & 75 & 17.3 & 119 & 27.4 & 3.583 & 1.035 & 71.66 & 23 \\
\hline 2 & $\begin{array}{l}\text { Are floors always cleaned and dried, and dirt and debris removed and chlorinated } \\
\text { efficiently? }\end{array}$ & 0 & 0.0 & 0 & 0.0 & 290 & 66.8 & 50 & 11.5 & 94 & 21.7 & 3.548 & 0.826 & 70.97 & 24 \\
\hline 2 & $\begin{array}{l}\text { Is a schedule for cleaning, disinfection and sterilization of machines, visions, } \\
\text { boxes, helmets, and tools periodically followed and its implementation followed } \\
\text { up? }\end{array}$ & 0 & 0.0 & 80 & 18.4 & 210 & 48.4 & 0 & 0.0 & 144 & 33.2 & 3.479 & 1.133 & 69.59 & 25 \\
\hline 2 & Do clean and disinfect surfaces and tools before and after circulation. & 0 & 0.0 & 0 & 0.0 & 340 & 78.3 & 0 & 0.0 & 94 & 21.7 & 3.433 & 0.825 & 68.66 & 26 \\
\hline 2 & $\begin{array}{l}\text { Is the shoe thoroughly disinfected with chlorine to avoid the transmission of the } \\
\text { virus? }\end{array}$ & 0 & 0.0 & 112 & 25.8 & 80 & 18.4 & 242 & 55.8 & 0 & 0.0 & 3.300 & 0.853 & 65.99 & 27 \\
\hline 2 & $\begin{array}{l}\text { Is the money being cleaned and disinfected continuously in the case of not } \\
\text { dealing with electronic payment }\end{array}$ & 112 & 25.8 & 0 & 0.0 & 128 & 29.5 & 50 & 11.5 & 144 & 33.2 & 3.263 & 1.553 & 65.25 & 28 \\
\hline 3 & A medical survey of all employees is done regularly & 0 & 0.0 & 80 & 18.4 & 260 & 59.9 & 94 & 21.7 & 0 & 0.0 & 3.032 & 0.633 & 60.65 & 29 \\
\hline 3 & The temperature of the workers is constantly measured & 0 & 0.0 & 160 & 36.9 & 180 & 41.5 & 94 & 21.7 & 0 & 0.0 & 2.848 & 0.751 & 56.96 & 30 \\
\hline 3. & $\begin{array}{l}\text { Develop a Prevention Plan through have medical exams measured } \\
\text { continuously? }\end{array}$ & 0 & 0.0 & 100 & 23.0 & 314 & 72.4 & 20 & 4.6 & 0 & 0.0 & 2.816 & 0.493 & 56.31 & 31 \\
\hline
\end{tabular}


Table (5): Distribution of the studied handlers according to attitudes and knowledge of food handlers $(\mathrm{n}=434)$

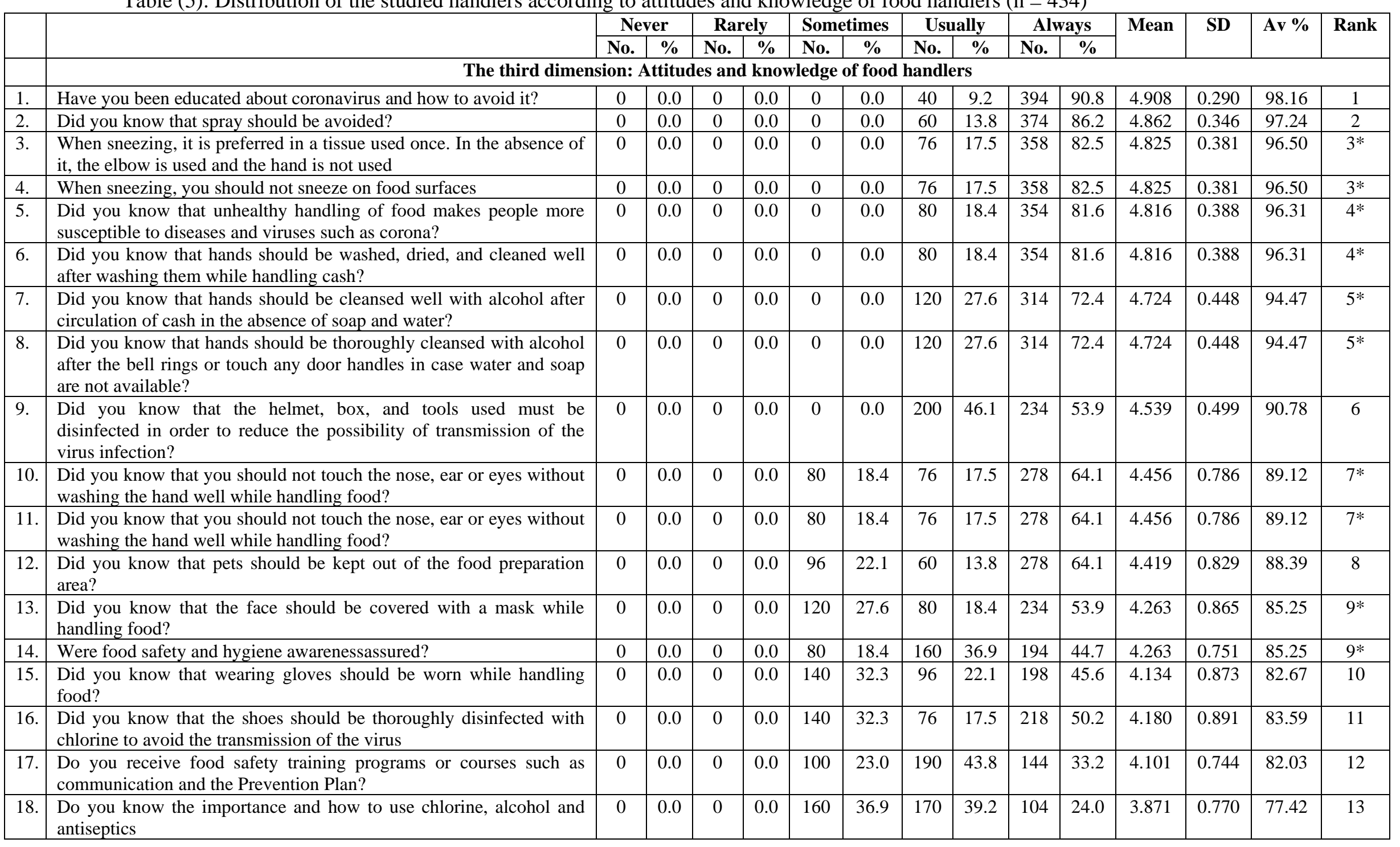


Table (6) showed that the mean scores of studied delivery handlers were in the first rank Attitudes and knowledge of food handlers by mean4.52andSD 0.53; followed in the next position by home delivery practices, with a mean 3.86and SD 0.74; finally in the third position Home delivery area andequipmentbymean 3.32and SD 0.86. This agrees with withH1: There is an effect of home delivery handlers' knowledge, attitudes and practices regarding food safety and COVID19 on the customer safety to avoid COVID-19 of selected restaurants.

Table (6): Descriptive analysis of the studied delivery handlers according to scores $(n=434)$

\begin{tabular}{|c|c|c|c|c|c|c|c|c|c|c|}
\hline & & \multirow{2}{*}{$\begin{array}{c}\text { Range } \\
\text { Statistic }\end{array}$} & \multirow{2}{*}{$\begin{array}{c}\text { Minimum } \\
\text { Statistic }\end{array}$} & \multirow{2}{*}{\begin{tabular}{r|} 
Maximum \\
Statistic
\end{tabular}} & \multirow{2}{*}{$\begin{array}{c}\text { Sum } \\
\text { Statistic }\end{array}$} & \multicolumn{2}{|c|}{ Mean } & \multirow{2}{*}{\begin{tabular}{|c|}
$\begin{array}{c}\text { Std. } \\
\text { Deviation }\end{array}$ \\
Statistic
\end{tabular}} & \multirow{2}{*}{$\begin{array}{l}\text { Variance } \\
\text { Statistic }\end{array}$} & \multirow[b]{2}{*}{ Rank } \\
\hline & & & & & & Statistic & $\begin{array}{c}\text { Std. } \\
\text { Error }\end{array}$ & & & \\
\hline hs1 & $\begin{array}{l}\text { Home delivery } \\
\text { area and } \\
\text { equipment }\end{array}$ & 2.47 & 2.06 & 4.53 & 1443.65 & 3.3264 & .04172 & .86915 & .755 & 3 \\
\hline hs2 & $\begin{array}{l}\text { Home delivery } \\
\text { practices }\end{array}$ & 2.19 & 2.69 & 4.88 & 1676.25 & 3.8623 & .03593 & .74854 & .560 & 2 \\
\hline hs 3 & $\begin{array}{l}\text { Attitudes and } \\
\text { knowledge of } \\
\text { food handlers }\end{array}$ & 1.50 & 3.50 & 5.00 & 1961.78 & 4.5202 & .02546 & .53043 & .281 & 1 \\
\hline
\end{tabular}

Nonparametric tests regarding Independent samples comparing the (hs1) home delivery area and equipment vs. (hs2) home delivery practices and Attitudes and knowledge of food handlers. As well as (hs1) home delivery area and equipment vs (hs3) Attitudes and knowledge of food handlers. Furthermore, (hs2) home delivery practices vs (hs3) home delivery area and equipment. Results showed that T-test value was significant at (0.00) in each dimension. This means that is revealed a statistically significant difference between the dimensions.

Table 7: Paired Samples T- Test of the variables compared to each other (N: 434)

\begin{tabular}{|c|c|c|c|c|c|c|c|c|c|}
\hline \multicolumn{8}{|c|}{ Paired Samples Statistics } & \multicolumn{2}{|c|}{$\begin{array}{c}\text { Paired Samples } \\
\text { Correlations }\end{array}$} \\
\hline & & Mean & $\begin{array}{c}\text { Std. } \\
\text { Deviation }\end{array}$ & $\begin{array}{c}\text { Std. Error } \\
\text { Mean }\end{array}$ & $\mathbf{t}$ & df & $\begin{array}{l}\text { Sig. (2- } \\
\text { tailed) }\end{array}$ & Correlation & Sig. \\
\hline \multirow{2}{*}{$\begin{array}{c}\text { Pair } \\
1\end{array}$} & hs1 & 3.3264 & .86915 & .04172 & $-68.569-$ & \multirow[t]{2}{*}{433} & \multirow[t]{2}{*}{.000} & \multirow[t]{2}{*}{.991} & \multirow[t]{2}{*}{.000} \\
\hline & hs2 & 3.8623 & .74854 & .03593 & & & & & \\
\hline \multirow{2}{*}{$\begin{array}{c}\text { Pair } \\
2\end{array}$} & hs1 & 3.3264 & .86915 & .04172 & $-58.519-$ & \multirow[t]{2}{*}{433} & \multirow[t]{2}{*}{.000} & \multirow[t]{2}{*}{.929} & \multirow[t]{2}{*}{.000} \\
\hline & hs3 & 4.5202 & .53043 & .02546 & & & & & \\
\hline \multirow{2}{*}{$\begin{array}{c}\text { Pair } \\
3\end{array}$} & hs2 & 3.8623 & .74854 & .03593 & $-44.505-$ & \multirow[t]{2}{*}{433} & \multirow[t]{2}{*}{.000} & \multirow[t]{2}{*}{.940} & \multirow[t]{2}{*}{.000} \\
\hline & hs3 & 4.5202 & .53043 & .02546 & & & & & \\
\hline
\end{tabular}

Moreover. Friedman Test as shown in table (8) show that the attitudes and knowledge of food handlers have the higher main rank and agree with $\mathrm{H} 1$ : There is an effect of home delivery handler's knowledge, attitudes and practices regarding food safety and COVID-19 on the customer safety to avoid COVID-19 of selected restaurants.

Table (8): a. Friedman Test(N. 434).

\begin{tabular}{|l|c|c|c|c|}
\hline \multicolumn{2}{|c|}{ Ranks } & \multicolumn{2}{c|}{ a. Friedman Test (N. 434). } \\
\hline & \multicolumn{1}{|c|}{ Mean Rank } & Chi-Square & df & Asymp. Sig. \\
\cline { 1 - 2 } hs1Home delivery area andequipment & 1.00 & 868.000 & 2 & .000 \\
\cline { 1 - 2 } hs2Home delivery practices & 2.00 & & & \\
\cline { 1 - 2 } hs3 Attitudes and knowledge of food handlers & 3.00 & & & \\
\hline
\end{tabular}

Regarding the research hypothesis test, there are statistically significant relationships between home delivery area, home delivery handlers knowledge, attitudes and practices of food safety against COVID-19 of selected restaurants, as shown in table 9 and Figure1. Results showed that there is a significant correlation between the food preparation area and practice, there is a significant positive correlation between home delivery area and equipment and home delivery 
practices and Attitudes and knowledge of home delivery handlers. With (r) values ranging from $(0.929)$ to $(0.991)(\mathrm{p}<.01) * *$. Correlation was significant at the 0.01 level (2-tailed).

Table (9): Correlation between knowledge, practice and attitude of home delivery handlers

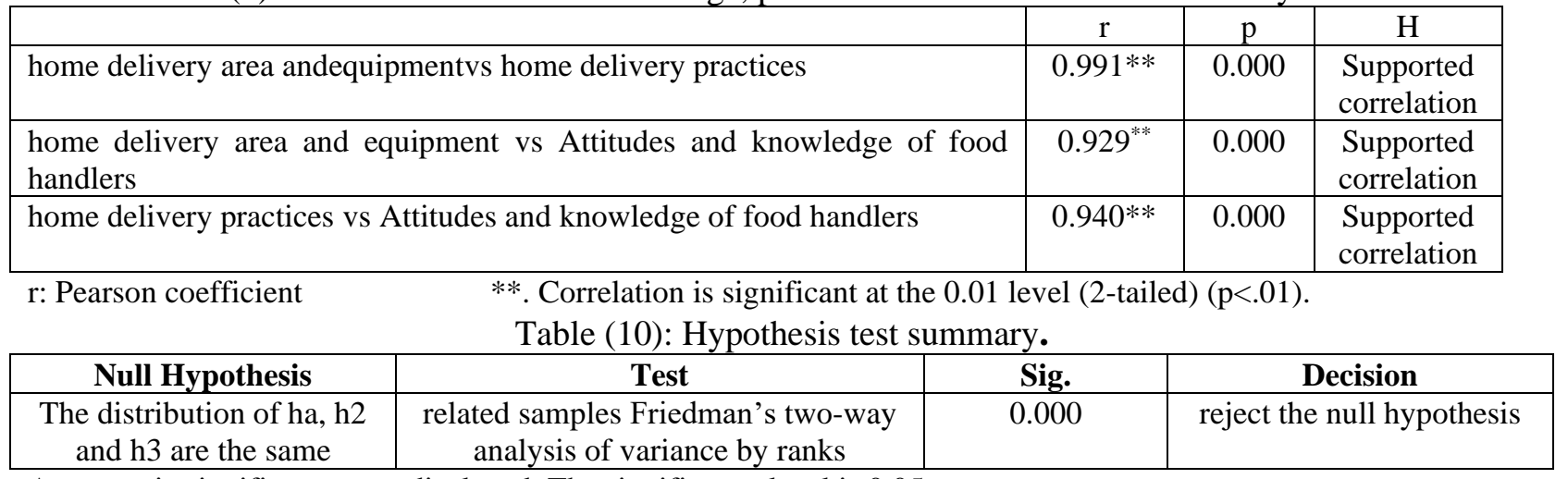

Asymptotic significances are displayed. The significance level is 0.05 .

\section{Discussion and Conclusion}

The Cronbach's Alpha reliability was computed, and the tests showed that the reliability coefficients for all the instruments were above 0.99 , which indicates that the instrument was reliable for being used.

According to The first dimension: Home Delivery Area and Equipment, the last position there is a health supervisor or doctor to follow by percentage (37.42); Is there no smoking in the delivery service area is the 16th efficiency average; Regarding 15th agree position where is a thermometer available to measure temperature; In the 14th position is the restaurant having internal COVID19 response team; concerning the $13^{\text {th }}$ level agrees average was that is the delivery handlers assured personal distance. Generally, Quick Service Restaurants should arm themselves with an internal COVID-19 response team to take action this agree with Mangan (2020); and World Health Organization (WHO) (2020c).

Rendering the second dimension: home delivery practices results showed that in accordance to the last position was that develop a Prevention Plan through have medical exams measured continuously, by percentage (56.31); The temperature of the workers is measured continuously is in the 30th efficiency average; Regarding 29th agree with the position where that medical survey of all employees is done regularly; In the 28thpositionis the money being cleaned and disinfected continuously in the case of not dealing; Concerning the $27^{\text {th }}$ level agrees that is the shoe thoroughly disinfected with chlorine to avoid the transmission of the virus this agree with World Health Organization (WHO) (2020a); andWorld Health Organization (WHO) (2020d).

According to the third dimension: Attitudes and knowledge of food handlers, the results showed that in accordance to the last position was that do delivery handlers know the importance and how to use chlorine, alcohol and antiseptics by percentage (77.42); Do delivery handlers food safety training programs or courses such as communication and the Prevention Plan was in the $12^{\text {th }}$ efficiency average; Regarding $11^{\text {th }}$ agree with the position where that did delivery handlers know that the shoes should be thoroughly disinfected with chlorine to avoid the transmission of the virus; In the 10thposition is did delivery handlers know that wearing gloves should be worn while handling food;Concerning the 9th level agrees with that both of was food safety and hygiene awareness assured, and did delivery handlers know that the face should be covered with a mask while handling food this agreed with Reeves et al. (2020); World Health Organization (WHO) (2020d).

Results showed that the mean scores of studied delivery handlers were in the first rank Attitudes and knowledge of food handlers; followed in the next position by home delivery practices; 
finallyinthe third position Home delivery area and equipment. This agrees with withH1: There is an effect of home delivery handlers knowledge, attitudes and practices regarding food safety and COVID-19 on the customer safety to avoid COVID-19 of selected restaurants.

There are statistically significant relationships between Home Delivery Handlers Knowledge, Attitudes and Practices of food safety against COVID-19 of selected restaurants. Results showed that there is a significant correlation between food preparation area and practice, there is a significant positive correlation between home delivery area and equipment; home delivery practices; attitudes and knowledge of home delivery handlers. With (r) values ranging from $(0.929)$ to $(0.991)(\mathrm{p}<.01)$ Correlation was significant at the 0.01 level (2-tailed).

\section{Recommendations}

These recommendations might help managers to improve better knowledge, attitudes and practices of home delivery handlers regarding avoid COVID-19 in Quick Service Restaurants. These recommendations were as follows:

1. Home Delivery Area and Equipment need more care about:

- A health supervisor or doctor should be available.

- There should no smoking in the delivery service area.

- A thermometer should be available to measure temperature.

- The restaurant should have an internal COVID-19 response team.

- Develop personalization and delivery handlers should assure personalization.

- Quick Service Restaurants should arm themselves with an internal COVID-19 response team.

2. Quick Service Restaurants should more care regarding home delivery practices such as:

- Develop a Prevention Plan.

- Have medical exams measured continuously.

- Regularly measured the home delivery handlers' temperature.

- Medical survey of all employees should be done regularly.

- the money being cleaned and disinfected continuously in the case of not dealing.

- the shoe thoroughly disinfected with chlorine to avoid the transmission of the virus

3. Quick Service Restaurants should more care about the Attitudes and knowledge of food handlers

- Delivery handlers should know the importance and how to use chlorine, alcohol and antiseptics.

- Delivery handlers' food safety training programs or courses such as communication and the Prevention Plan are required frequently.

- Delivery handlers should know that the shoes should be thoroughly disinfected with chlorine to avoid the transmission of the virus.

- Delivery handlers know that wearing gloves should be worn while handling food;

- Improve food safety and hygiene awareness;

- Delivery handlers know that the face should be covered with a mask while handling food.

4. Assess the impact of COVID-19 on the restaurant business.

5. Consider the direct advantages and disadvantages.

6. Reevaluate the markets that remain strong.

7. Market to loyalty members. 


\section{References}

Curtis, S. (2016). Pizza hut hires ROBOT waiters to take orders and process payments at its fastfood restaurants. Mirror. Retrieved on December 3, 2018, from https://www.mirror.co.uk/tech/pizza-hut-hires-robot-waiters-8045172

Fuchs, C. (2020a). Everyday life and everyday communication in coronavirus capitalism. Communication, Capitalism \& Critique, 18(1), 375-399.

Fuchs, C. (2020b). Communication and Capitalism. A Critical Theory. London: University of Westminster Press.

Fuchs, C. (2020c). Nationalism on the Internet: Critical Theory and Ideology in the Age of Social Media and Fake News. New York: Routledge.

Gupta, M. (2019). A Study on Impact of Online Food delivery app on Restaurant Business special reference to zomato and swiggy. International Journal of Research and Analytical Reviews, 6(1), 889-893.

Hill, S. (2015). Restaurant table tablets: A gimmick, or actually helpful? The Christian Science Monitor. Retrieved on March, 2020, from https://www.csmonitor.com/ Business/Saving-Money/2015/0514/Restaurant-table-tablets-A-gimmick-or-actuallyhelpful

Jacob, A.M.; Sreedharan, N., \& Sreena, K. (2019). Consumer perception of online food delivery apps in Kochi. International Journal of Innovative Technology and Exploring Engineering, 8(752), 302-305.

Li, X.; Song, Y.; Wong, G., \& Cui, J. (2020). Bat origin of a new human coronavirus: there and back again. Science China Life Sciences, 63(3), 461-462.

Mangan, D. (2020). Trump blames China for coronavirus pandemic: 'The world is paying a very big price for what they did'. Retrieved on April, 2020, from https://www.cnbc.com/2020/03/19/coronavirus-outbreak-trump-blames-china-for-virusagain.html

Martínez-Álvarez, F.; Asencio-Cortés, G.; Torres, J.; Gutiérrez-Avilés, D.; Melgar-García, L.; Pérez-Chacón, R., . . \& \& Troncoso, A. (2020). Coronavirus Optimization Algorithm: A bioinspired metaheuristic based on the COVID-19 propagation model. Retrieved, from https://arxiv.org/pdf/2003.13633.pdf

Priyadharshini, R. (2017). Consumer perception towards MNC fast food outlets in Coimbatore. International Journal of Applied Research, 3(3), 237-240.

Rathore, S.S., \& Chaudhary, M. (2018). Consumer's Perception on Online Food Ordering. International Journal of Management \& Business Studies, 8(4), 12-17.

Reeves, M.; Lang, N., \& Carlsson-Szlezak, P. (2020). Lead your business through the coronavirus crisis. Harvard Business Review, 27, 1-7.

Singh, A.; Pathan, S., \& Kanade, V. (2017). Online Food Ordering System International Journal of Computer Applications, 180(6), 22-24(6), 22-24.

Tabish, S.A. (2020). Coronavirus. Responding to the challenge of coronavirus (2019-ncov) pandemic, technical report

Trejos, N. (2015). Marriott to hotel guests: We're app your service. USA Today. Retrieved on February, 2020, from https://www.usatoday.com/story/travel/ 2015/05/13/marriotthotels-mobile-requests-two-way-chat/27255025/

World Health Organization (WHO). (2020a). COVID-19 and Food Safety: Guidance for Food Businesses: interim guidance. Geneva, Switzerland: WHO.

World Health Organization (WHO). (2020b). WHO Announces COVID-19 Outbreak a Pandemic. Geneva, Switzerland: WHO. 
World Health Organization (WHO). $\left(2020^{c}\right)$.

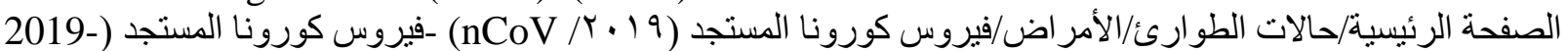

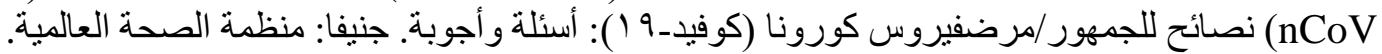

World Health Organization (WHO). (2020d). World Experts and Funders Set Priorities for COVID-19 Research. Geneva, Switzerland: WHO.

Zhu, N.; Zhang, D.; Wang, W.; Li, X.; Yang, B.; Song, J., \& Lu, R. (2020). A novel coronavirus from patients with pneumonia in China, 2019. New England Journal of Medicine, 382, 727-733. 